\title{
UBTF Gene
}

National Cancer Institute

\section{Source}

National Cancer Institute. UBTF Gene. NCI Thesaurus. Code C147961.

This gene is involved in the transcription of ribosomal RNA genes. 